\title{
FORMATION OF THE FUTURE TRANSLATORS INDIVIDUAL STYLE
}

\section{${ }^{a}$ OLEH LAVNIKOV, ${ }^{\mathrm{b}}$ HANNA LESHCHENKO, ${ }^{c}$ LIUDMYLA MAKSYMENKO, ${ }^{d}$ ARTUR STANISHOVSKYI, ${ }^{e}$ NATALIIA VOVCHASTA, ${ }^{f}$ OLGA SHELIUKH}

${ }^{a}$ Department of Innovative Technologies in Pedagogy, Psychology and Social Work, Alfred Nobel University, Dnipro, Ukraine, ${ }^{\mathrm{b}}$ Applied Linguistics and Translation Department, Cherkasy State Technological University, Ukraine, ${ }^{c}$ Department of the English Language and Translation, Kyiv National Linguistic University, Ukraine, ${ }^{d}$ Department of mobilization, personnel organization and defence planning, Hetman Petro Sahaidachny National Army Academy, Lviv. Ukraine,

${ }^{e}$ Department of Foreign Languages, Lviv Polytechnic National University, Ukraine, ${ }^{+}$Department of Humanities, Hetman Petro Sahaidachnyi National Army Academy, Lviv. Ukraine email: ${ }^{a}$ swan_ov@ukr.net, ${ }^{b} a n l e s \_u a @ u k r . n e t$, 'l.o.maksymenko@gmail.com, ${ }^{d}$ arturstepanovi4@gmail.com, enatvovchasta@gmail.com, ${ }^{f}$ dolynyuk25@gmail.com

Abstract: The aim of this article is to study the peculiarities of the formation of the individual style of future translators in the context of the implementation of a systematic approach, based on the experience of higher education institutions that train translators in accordance with market needs. It is determined that the most spoken languages are English, Mandarin Chinese, Hindi, Spanish and French, which are spoken by more than 3.67 billion people in the world, and according to the largest number of native speakers - Mandarin Chinese and Spanish. Installed that the leading institutions of higher education, which occupy the highest positions in the world in the field of education of students majoring in translation, are the Massachusetts Institute of Technology and the University of Massachusetts Amherst.

Keywords: Profession of Translator, Translation Activity, Institution of Higher Education, Digital Technologies.

\section{Introduction}

With the development of market relations, the labor market places new demands on employees. This is especially true for translators, because the level and quality of their translation activities depends on the results of different areas and levels of activity. Today, the training of students who master the profession of translator, involves mastering the language to a high level. However, practice shows that students, having acquired the profession of a translator, are not always able to carry out translation activities at a high level, qualified, highquality and professional.

This to some extent indicates the imperfection of the curriculum of students as future translators. As a solution, it is necessary to clearly outline the key advantages and disadvantages of such a program and in the long run to eliminate the problems that affect the process of forming the individual style of future translators.

\section{Literature review}

Considering the role of modern digital technologies in the training of future translators, Besznyák et al. (2020) emphasize the need to develop a special translation program, which should be based on a sufficient level of theoretical basis necessary for the development of practical translation skills.

Ivleva et al. (2017), examining the importance of using the SmartCAT cloud platform to train future translators, note that such technology can significantly reduce the time required for translators to translate. According to scientists, SmartCAT technology is one of the effective means of machine translation used by modern translators. In addition, researchers compared how the use of SmartCAT technology affects the success of translators. According to the results of the study, it was found that SmartCAT technology should be a mandatory component of the curriculum, which is the training of future translators. Van Egdom et al. (2018) note that an important place in the training of future translators is occupied by ergonomics, due to which the translation activity is successfully combined with the use of modern technologies. Thanks to ergonomics, according to scientists, it is possible to solve both cognitive and physical, professional or organizational problems, as well as to form in future translators the idea of the importance of sustainable translation.

Krajcso (2018) notes that the formation of a profile of translators 'competence is important in the context of students' studies as a translator, and it should be much higher than what is offered by the market. that (2019) argues that for the formation of translation competencies in students who acquire the profession of translator, it is necessary to improve the corpus learning, which is based on the improvement of corpus linguistics. Golubkova et al. (2017) emphasize that in the context of training future translators, their socio-cultural competence should be developed. Thus, according to scientists, the cultural component should be one of the key components that underlie the curriculum for training students majoring in translation. Bogush et al. (2019) note that the development of their professional competence is no less important in the context of training future translators. After conducting research, the researchers concluded that the use of context-oriented and competency-oriented approaches in the training program for future translators would significantly increase their success rate. Tarasenko et al. (2019) note the importance of the formation of information competence in future translators through the development of informationthematic component of information competence. The formation of this type of competence will allow students, as future translators; to better master the terminology. Hirci (2017) argues that in preparing students as future translators, special attention should be paid to the acquisition of pronunciation skills in the languages whose translations students will work on in the future. According to the scientist, the development of language skills increases the chances of students, as future translators, for successful employment. Berthaud et al. (2018) emphasize that future translators, after graduating from higher education institutions and acquiring the profession of translator, must definitely improve their skills by participating in postgraduate translation programs.

Popova et al. (2017) as a result of the study noted that an important role in the process of students, as future translators, success in learning, plays primarily the initial stage of their education, as it lays the foundation for further process of acquiring new knowledge, skills, and abilities to learn foreign languages. Portelli (2018) notes that translators, as cultural intermediaries, significantly influence students' mastery of the profession of translator. The researcher also proposes to include a component of cultural awareness in the training program for future translators. This will allow students to better understand cultural values and the fact that their role as a cultural mediator is very important. Sanchez (2017) notes that in the context of preparing students for the profession of translator, it is advisable to focus on the practical aspect, in particular on cooperation with professional translators. In the educational process, according to the scientist, should also use modern teaching methods. Simkova (2017) notes that in order to train highly qualified translators, training programs should be designed and implemented based on the professional standards on which the field of work of translators is based. Also, according to the scientist, special attention should be paid to improving the quality of education in the field of training students majoring in translation.

Pietrzak (2019) notes that effective training of future translators can be ensured by solving problems that arise in the context of preparing students for the level of experienced translators, and a clear set of goals in the curriculum, which provides a holistic procedure for developing real skills in translation. Drugan (2017) notes that in the context of the curriculum for the preparation of students majoring in translation, the requirements of ethics and social responsibility should be taken into account. According to the scientist, highly qualified translators should perform their work based on ethical aspects and feel social responsibility, taking into account the interests of society. Li (2017) argues that it is advisable to use different 
translation techniques to train future translators. This will allow future translators to choose the technique that best reveals the content of the translated in the future. Cruz García (2017) emphasizes that in the context of teaching students who master the profession of translator, it is advisable to pay special attention to the lexical, morphological, semantic and syntactic principles of translation that underlie teaching methods. Loock (2017) notes that students who acquire the profession of translator, in the context of learning, it is advisable to form a vision of preserving the originality and grammatical correctness of the text that will be translated by them in the process of translation. At the heart of this method of teaching students is a feature of the naturalness of the language of translation, which improves the quality of translation.

Garcés et al. (2019) focus on the training of future translators as state translators. At the same time, researchers conclude that students who will become state translators in the future will be able to address various issues related to migration. Having studied the main trends in the modern training of future translators, the researchers noted that the programs, which prepare students to acquire such a specialty, need to be significantly improved. Hussein (2021) considers the peculiarities of training students as future translators who will work in the social sphere in the future, in particular, to communicate with foreign minors who are not accompanied by adults. To ensure highly professional training of such students, the researcher offers in the program, which is taught, focus on the social sphere and the sphere of public administration. Federici et al. (2018) also consider the features of teaching students as future civil translators. According to researchers, in order to train translators who will work in the social sphere, it is necessary to better standardize educational materials and provide support for the educational process with modern information and communication technologies. Valero-Garcés (2019) explores the peculiarities of the formation and implementation of the training course on a permanent basis, which provides for the training of administrative translators, i.e. those who will eventually work in government agencies (public administrations). Considering the principles of professional training of future translators, it should be noted that the problems of forming an individual style of future translators are not fully disclosed.

The aim of the article is to study the peculiarities of the formation of the individual style of future translators in the context of the implementation of a systematic approach, based on the experience of higher education institutions that train translators in accordance with market needs. To achieve the purpose of this article we should solve the following tasks:

- $\quad$ establish the most common languages in the world;
- to identify the leading educational institutions of higher education, which occupy the highest positions in the world in the field of education of students majoring in translation;

- present the most popular programs for learning languages that have a fairly high user rating;

- explore the features and present a method of forming the individual style of future translators;

- identify the advantages and disadvantages of the method of forming the individual style of future translators;

- present the components and algorithm for implementing a systematic approach to the formation of individual style of future translators.

\section{Materials and research methods}

During the achievement of the research goal the following were used: 1) methods of analysis, description, observation, abstraction, comparison to present the theoretical and practical bases of research of features of formation of individual style of future translators in the context of system approach; 2) methods of tabular and graphical representation - to identify the most common languages in the world and identify the leading higher education institutions that occupy the highest positions in the world in the field of study of students majoring in translation; 3) methods of experiment, modeling and generalization - to study the peculiarities of the formation of individual style of future translators in the context of a systematic approach, based on the experience of higher education institutions that train translators in accordance with market needs.

The information base of the study are the following indicators:

- rating of languages according to the indicator of colloquiality and the indicator of the largest number of speakers (Wordtips, 2021);

- ranking of universities in the field of "Linguistics" in The QS World University Rankings (Quacquarelli Symonds, 2018; Quacquarelli Symonds, 2021).

\section{Results}

A study by Wordtips (Wordtips, 2021) showed that today there are more than 7,000 vernacular languages in the world. Moreover, the most spoken languages are English, Mandarin Chinese, Hindi, Spanish and French, which are spoken by more than 3.67 billion people in the world (Table 1). Instead, if we pay attention to the indicator of the largest number of native speakers, the leader is Mandarin Chinese and Spanish. As for Ukrainian, it ranked 44th in terms of conversation, as Ukrainian is spoken by more than 33 million people. Instead, only 27 million people are Ukrainian speakers.

Table 1: Ranking of languages on the indicator of colloquiality and the indicator of the largest number of speakers

\begin{tabular}{|c|c|c|c|c|c|}
\hline \multirow[b]{2}{*}{ Language } & \multicolumn{2}{|c|}{ Conversation rate } & \multicolumn{2}{|c|}{ The largest number of carriers } & \multirow[b]{2}{*}{ Language Origin } \\
\hline & Rank & $\begin{array}{c}\text { Number of } \\
\text { million people }\end{array}$ & Rank & $\begin{array}{c}\text { Number of } \\
\text { million people }\end{array}$ & \\
\hline English & 1 & 1132 & 3 & 379 & Indo-European \\
\hline Mandarin Chinese & 2 & 1117 & 1 & 918 & Sino-Tibetan \\
\hline Hindi & 3 & 615 & 4 & 341 & Indo-European \\
\hline Spanish & 4 & 534 & 2 & 460 & Indo-European \\
\hline French & 5 & 280 & - & - & Indo-European \\
\hline Standard Arabic & 6 & 274 & - & - & Afro-Asian \\
\hline Bengali & 7 & 265 & 5 & 228 & Indo-European \\
\hline Russian & 8 & 258 & 7 & 154 & Indo-European \\
\hline Portuguese & 9 & 234 & 6 & 221 & Indo-European \\
\hline Indonesian & 10 & 199 & - & - & Austronesian \\
\hline Japanese & - & - & 8 & 128 & Japanese \\
\hline Western Punjabi & - & - & 9 & 93 & Indo-European \\
\hline Marathi Hindi & - & - & 10 & 83 & Indo-European \\
\hline$\ldots$ & $\ldots$ & $\ldots$ & $\ldots$ & $\ldots$ & $\ldots$ \\
\hline Ukrainian & 44 & 33 & - & 27 & Indo-European \\
\hline
\end{tabular}

Source: Wordtips, 2021.

Emphasizing the popularity and prevalence of languages, it is advisable to single out the leading educational institutions of higher education, which occupy the highest positions in the world in the field of education of students majoring in translation. A study by British consulting firm Quacquarelli
Symonds (Quacquarelli Symonds, 2018; Quacquarelli Symonds, 2021) found that the Massachusetts Institute of Technology (MIT) and University of Massachusetts Amherst (Amherst, United States), who's overall score is higher than 90 points (Fig. 1). 


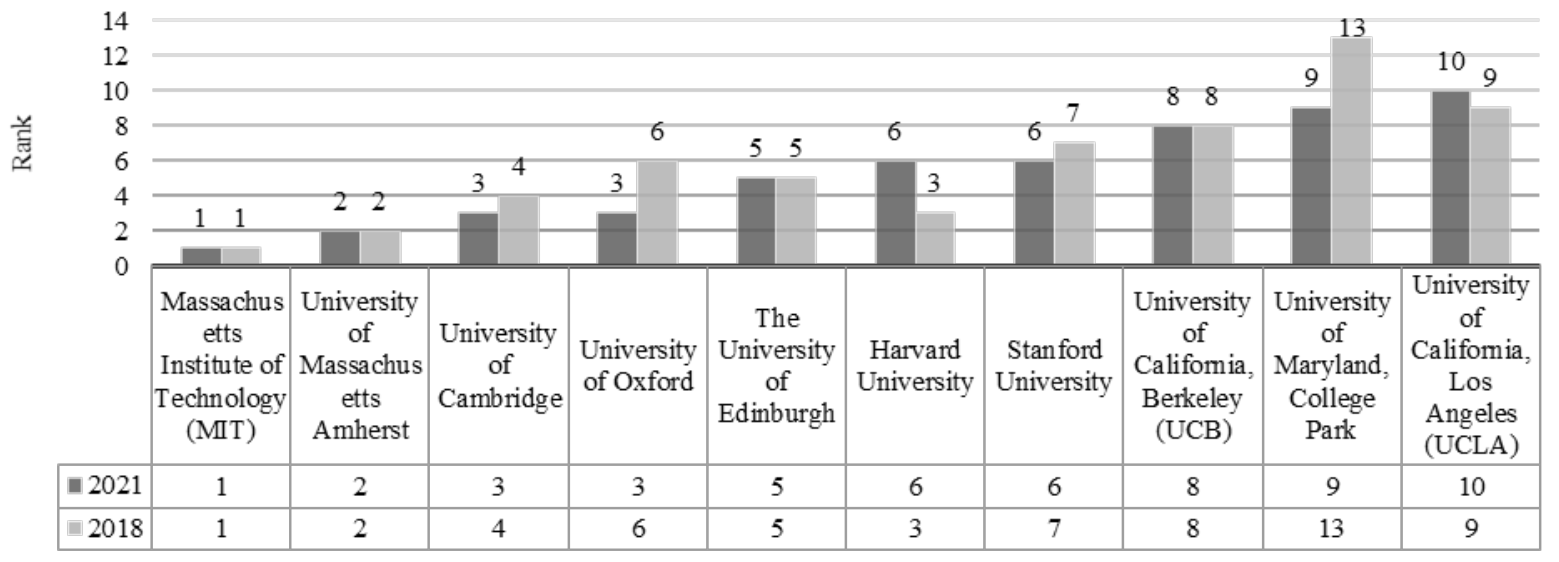

Figure 1 - University ranking in the field of "Linguistics” in The QS World University Rankings Source: Quacquarelli Symonds, 2018; Quacquarelli Symonds, 2021

Research shows that the most popular institutions of higher education (Fig. 1), providing training in the field of "Linguistics" are concentrated in two countries - the United States and the United Kingdom.

Regarding Ukraine, in the field of "Philology", the International Scientific carries out the training of future translators and Technical University named after Academician Yuriy Bugay (MNTU), Open International University of Human Development "Ukraine”, Kyiv National Linguistic University, and National Pedagogical University named after $M$. Drahomanov and others.

Analysis of the features of language learning will allow us to identify the 15 most popular, but at the same time the best programs for language learning, which have a fairly high rating of use by users. Thus, according to Effective Language Learning (Effective Language Learning, 2020), the most popular programs designed for language learning are: 1) Speed Learning Languages Review; 2) Fluenz Review; 3) Duolingo Review; 4) Babbel review; 5) Rosetta Stone Review; 6) Memrise Review; 7) Busuu Review; 8) Pimsleur Review; 9) Mondly Review; 10) Michel Thomas Review; 11) Rocket Languages Review; 12) eLanguage Review; 13) Tell Me More Review; 14) Instant Immersion Review; 15) Berlitz Review. Moreover, Speed Learning Languages Review and Fluenz Review have a high level of application efficiency. Instead, the most interactive programs are Duolingo Review and Rosetta Stone Review.

Emphasizing the peculiarities of the formation of individua style of future translators, it should be noted that the basis of a systematic approach to the formation of individual style of future translators should be the development of individual curriculum based on competencies, knowledge, skills and abilities of students. Before forming groups in which students will study while receiving education in higher education institutions, it is necessary to assess the level of knowledge, skills and abilities of such students. According to the results of such assessment, students should be divided into groups that demonstrate a high level of mastery of a foreign language (or foreign languages), a medium level of mastery of a foreign language (or foreign languages) and a low level of mastery of a foreign language (or foreign languages).

At the end of each semester, students must take a language test. This aspect of assessment will determine the level of knowledge acquired during the semester. As a result, students who showed a high level of knowledge, skills and abilities acquired during the semester are enrolled in groups with a high level of foreign language proficiency, students who showed an average level - in groups with an average level of foreign language proficiency, and students who showed low level - to groups with a low level of foreign language proficiency. Students in such groups continue their studies in the next semester, and their preparation

in the field of translating takes place to a specially designed individual study plan for each of the groups. It should be noted that the individual curriculum for each of the groups is formed accordingly to address the problems and difficulties that arise in the way of language acquisition.

It is advisable to note that the proposed method has several drawbacks, since, taking into account the distribution of students in groups according to their knowledge and skills. In this manner, the distribution of students in groups can occur deterioration of the socio-psychological climate among students in the group. In study groups, relationships are formed between students - students become friends, and according to the results of language testing, they can continue their studies in another study group, where their student friends will not study. In addition, the self-esteem of those students who were in the first semester of study, for example in a group with a high level of foreign language proficiency, and according to the results of language testing, passed into a group with medium or low level of foreign language proficiency.

The advantages of this method of teaching are the motivation to get into a group with a high level of mastery of a foreign language or to continue to study in such a group. In addition, the curriculum should provide that translators at leading translation agencies might in the future employ students who successfully complete higher education and demonstrate a high level of proficiency in a foreign language (or languages). This condition of graduation will act as a motivating factor to acquire better knowledge, skills and abilities.

As for the individual style of training students who master the profession of translator, the curriculum should include the following items:

- The student, mastering the profession of translator, must clearly understand that in translation activities should adhere to the social, ethnographic, cultural and at the same time ethnic context.

- In translation activities, high equivalence and quality of translation should be achieved by preserving the content, stylistic, semantic, functional and communicative information presented in the original.

Thus, focusing on the above, the basis of a systematic approach to the formation of the individual style of future translators should be the following components (the weight of which is presented in Fig. 2): 
- $\quad$ setting goals and objectives of the training program for future translators;

- rational teaching of educational material by highly qualified teachers with a high level of pedagogical skills, professionalism, psychological culture, competence, creative potential;

- involvement of experienced translators-practitioners in the educational process in order for students to acquire practical skills of translation activity in lectures and practical classes;

- participation of students majoring in translator in international conferences, webinars, round tables in order to gain experience, exchange experiences and achievements with other students;

- $\quad$ internships for students abroad in partner higher education institutions and companies in order to better master the languages in the context of direct communication with native speakers;

- $\quad$ sending students for internships at a translation agency in order to understand the requirements of the labor market for a modern translator;

- $\quad$ exchange of students with foreign institutions of higher education-partners in order to improve the level of practical skills not only of students studying abroad, but also students who will study with foreign students directly in the institution of higher education;

- the use of modern information and communication technologies in the educational process to facilitate students' perception of educational material, the acquisition of practical skills in the context of relationships with native speakers of the language they are learning.

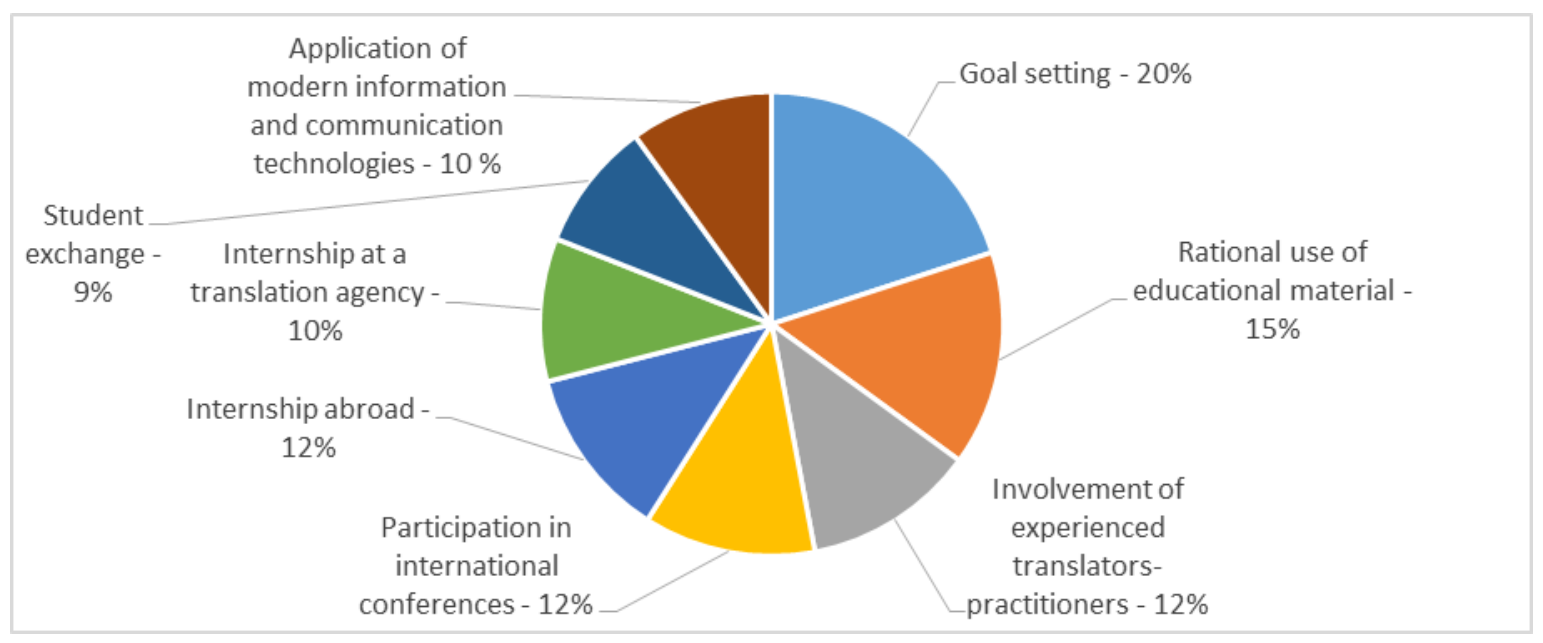

Figure 2 - The importance of the components of a systematic approach to the formation of the individual style of future translators, \%

In identifying the components of a systematic approach to the formation of individual style of future translators should present a comprehensive algorithm for implementing such an approach, based on the experience of the International Scientific and Technical University named after Academician Yuriy Bugay (MNTU) (Mizhnarodnyj naukovo-tekhnichnyj universytet imeni akadem , 2021), Open International University of Human Development "Ukraine" (Vidkrytyj mizhnarodnyj universytet rozvytku ljudyny "Ukraine”, 2021), Kyiv National Linguistic University (Kyjivsjkyj nacionaljnyj linghvistychnyj universytet, 2021), National Pedagogical University named after M. Dragomanov (National Pedagogical University named after M.P. Draghomanov, 2021) (Fig. 3).

Thus, the results of the study allowed to present the features of the formation of individual style of future translators in the context of a systematic approach, based on the experience of the International Scientific and Technical University named after Academician Yuriy Bugay (MNTU), Open International University of Human Development "Ukraine”, Kyiv National Linguistic University, National Pedagogical University named after M. Dragomanov. It is established that in order to form the individual style of future translators it is necessary to develop an individual curriculum based on the competencies, knowledge, skills and abilities of students who master the profession of translator. The proposed curriculum aims to conduct language testing at the end of each semester,

The practical significance of the proposed approach is that it will increase the level of foreign language proficiency, as students who are interested in successful employment in the field of translation (and this is one of the conditions of the curriculum) are required to master a foreign language.

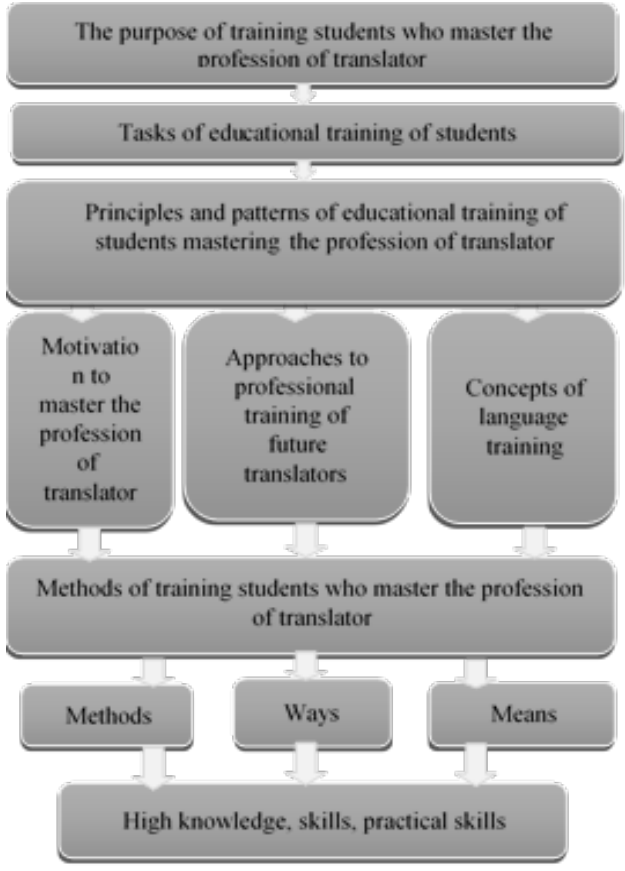

Figure 3 - Algorithm for implementing a systematic approach to the formation of individual style of future translators

\section{Discussion}

According to the results of the study of the peculiarities of the formation of the individual style of future translators in the 
context of the implementation of a systematic approach, the special relevance of the issue professional training of future translators in the research of many scholars. Namely, scientists note that the formation of the individual style of future translators is through:

- development of a special translation program, which should be based on a sufficient level of theoretical basis necessary for the development of practical translation skills (Besznyák et al., 2020);

- the use of the cloud platform SmartCAT (Ivleva et al. 2017), ergonomics, which combines translation with the use of modern technologies (Van Egdom et al., 2018);

- formation of the profile of translators' competence (Krajcso, 2018), formation of translation competencies (Otăt, 2019), development of socio-cultural competence (Golubkova et al., 2017), development of professional competence (Bogush et al., 2019), the formation of information competence (Tarasenko et al. 2019),acquisition of pronunciation skills of the languages in which the translation activity will be carried out (Hirci, 2017), raising the level of qualification due to participation in postgraduate translation programs (Berthaud et al., 2018);

- primary education, as at this stage the basis for furthe process of acquiring new knowledge, skills and abilities in the direction of learning foreign languages (Popova et al., 2017), participation and cooperation with professional translators as cultural mediators who significantly influence the development students of the profession of translator (Portelli, 2018; Sanchez, 2017), the formation and implementation of educational programs, based on professional standards on which the field of work of translators is based (Simkova, 2017);

- solving problems that arise in the context of preparing students for the level of experienced translators (Pietrzak, 2019),taking into account the requirements of ethics and social responsibility (Drugan, 2017),application of different translation techniques ( $\mathrm{Li}, 2017)$, taking into accountlexical, morphological, semantic and syntactic principles of translation that underlie teaching methods (Cruz García, 2017),forming a vision of preserving the originality and grammatical correctness of the text that will be translated in the process of translation (Loock, 2017).

It is worth agreeing with the results obtained by scientists, but according to the relevance of the issue, the study of the individual style of future translators in the context of a systematic approach should be based on the experience of higher education institutions, for example the experience of Yuriy Bugay International University of Science and Technology (MNTU), Open International University of Human Development “Ukraine”, Kyiv National Linguistic University, National Pedagogical University named after M. Dragomanov.

As a result of the research for the formation of individual style of future translators it is proposed to develop and implement a special and at the same time individual curriculum by institutions of higher education that train students - future translators.

This program should take into account the individual competencies, knowledge, skills and abilities of students who master the profession of translator. The proposed program should be based on language testing at the end of each semester in order to determine the level of foreign language proficiency of students. According to the results of language testing, the program proposes to divide students into groups (groups with a high level of foreign language proficiency, groups with a medium level of foreign language proficiency, groups with a low level of foreign language proficiency).

\section{Conclusion}

It is established that the formation of the individual style of future translators depends on the result of the development of professional, socio-cultural, informational competencies. It was found that the use of cloud platform SmartCAT and other information and communication technologies significantly affects the individual style of the future translator. It is determined that a special translation program should be developed to increase the level of language proficiency.

To study the peculiarities of the formation of the individual style of future translators in the context of the implementation of a systematic approach, it is necessary to rely on the experience of higher education institutions that train translators in accordance with market needs. In the study, the implementation of systemic to the formation of individual style of future translators was based on the experience of the International Scientific and Technical University named after Academician Yuriy Bugay (MNTU), Open International University of Human Development "Ukraine”, Kyiv National Linguistic University, National Pedagogical University named after M. Dragomanov.

It was found that the formation of individual style of future translators is based on understanding the translation of social, ethnographic, cultural and ethnic context in translation, as well as achieving high equivalence and quality of translation by preserving the content, stylistic, semantic, functional and communicative information, filed in the original.

It is proved that in order to form an individual style of future translators it is necessary to develop an individual curriculum based on the competencies, knowledge, skills and abilities of students mastering the profession of translator and implement it in higher education institutions that train future translators. It is proposed to determine the components of a systematic approach to the formation of the individual style of future translators: 1 ) setting goals and objectives; 2) rational use of educational material; 3) involvement of experienced translatorspractitioners; 4) participation in international conferences, webinars, round tables; 5) internship abroad; 6) internship at a translation agency; 7) exchange of students; 8) application of modern information and communication technologies.

It is established that the basis for the implementation of a systematic approach to the formation of individual style of future translators is: 1) the purpose of training students who master the profession of translator; 2) the task of training students who master the profession of translator; 3) principles and regularities of educational training of students mastering the profession of translator; 4) motivation to master the profession of translator, approaches to the training of future translators and the concept of language training; 5) methods of training students who master the profession of translator; 6) methods, ways and means. As a result of the gradual implementation of such items, high knowledge, skills, practical skills in the field of professional translation activities are formed.

The practical significance of the results obtained in the study indicates that the systematic approach, which provides for the formation of the individual style of future translators, is of universal importance. Because of adjusting this approach in accordance with the peculiarities of other areas of student training, higher education institutions can apply it.

In the perspective of further explorations, a study of the peculiarities of the formation of competencies in future translators is planned in order to increase the level of language proficiency.

\section{Literature:}

1. Berthaud, S., \& Mason, S. (2018). Embedding reflection throughout the postgraduate translation curriculum: using 
Communities of Practice to enhance training. The Interpreter and Translator Trainer, 12(4), 388-405. https://doi.org/10. 1080/1 750399X.2018.1538847

2. Besznyák, R., Fischer, M., \& Szabó, C. (2020). Fit-ForMarket Translator and Interpreter Training in a Digital Age. Vernon Press, 245.

3. Bogush, A., Korolova, T., \& Popova, O. (2019). Development of the future translators' professional competency in bilateral interpreting: modern methods. Advanced education, 11, 10-21. https://doi.org/10.20535/2410-8286.156577

4. Cruz García, L. (2017). Foreign Language Training in Translation and Interpreting Degrees in Spain: a Study of Textual Factors. Revista Digital De Investigacion En Docencia Universitaria-Ridu, 11(2), 75-89.

5. Drugan, J. (2017). Ethics and social responsibility in practice: interpreters and translators engaging with and beyond the professions, The Translator, 23(2), 126-142. https://doi.org/10.1080/13556509.2017.1281204

6. Effective Language Learning (2020). Top 15 Language Learning Apps. Retrieved from https://effectivelanguage learning.com/language-course-reviews/

7. Federici, F. M., \& Cadwell, P. (2018). Design and delivery of bespoke training on the fundamentals of translation for New Zealand Red Cross. Translation Spaces, 7(1), 20-43. https://doi.org/10.1075/ts.00002.fed

8. Garcés, V. \&, Carmen, M. (2019). Training public service interpreters and translators: facing challenges. Revista de Llengua i Dret, 71, 88-105. https://doi.org/10.2436/rld.i 71.2019 .3262

9. Golubkova, O. N., Masalimova, A. R., \& Bírová, J. (2017). The development of sociocultural competence in future translators via the methodology of culture-oriented interpretation of English language fictional texts. Man In India, 97(14), 73-83.

10. Hirci, N. (2017). Investigating trainee translators' views on the pronunciation of English: a Slovene perspective. Linguistica, 57(1), 93-106. https://doi.org/10.4312/linguistica.5 7.1.93-106

11. Hussein, H. S. (2021). The Challenge of Training Translators and Interpreters in the Social Context of Foreign Unaccompanied Minors. AWEJ for Translation \& Literary Studies, 5(1), 20-39. http://dx.doi.org/10.24093/awejtls/vo l5no1.2 12. Ivleva, M. A., \& Melekhina, E. A. (2017). Cloud Platform SmartCAT in Teaching Future Translators. Linguistic and Cultural Studies: Traditions and Innovations. LKTI 2017. Advances in Intelligent Systems and Computing, 677. https://doi.org/10.1007/978-3-319-67843-6_19

13. Krajcso, Z. (2018). Translators' competence profiles versus market demand. Babel, 64(5-6), 692-709. https://doi.org/10.10 75/babel.00059.kra

14. Li, Li (2017). Training undergraduate translators: consciousness-raising approach. The Interpreter and Translator Trainer, 11(4), 245-258. https://doi.org/10.1080/1750399X.201 7.1359757

15. Loock, R. (2017). Because Grammatically Correct is not Enough: Grammatical Naturalness in the Target Language as the Icing on the Cake for Future Translators. COLLOQUE, 24. 16. Oțăt, D. (2019). Corpus-based training to build translation competences and translators' self-reliance. Romanian Journal of English Studies,14, 107-113. https://doi.org/10.1515/rjes2017-00123

17. Pietrzak, P. (2019). The potential of reflective translator training. intralinea Special Issue: New Insights into Translator Training. http://www.intralinea.org/specials/article/2431 18. Popova, O. V., \& Yakovleva, O. (2017). Initial Education Stage as the Determinant of Future Translators' Further Academic Success. Nauka i osvita, 12, 5-14.
19. Portelli, S. (2018). The role of translators as cultural mediators and its implications in the training of prospective Maltese translators. Symposia Melitensia, 14, 357-365.

20. Kyjivsjkyj nacionaljnyj linghvistychnyj universytet (2021). Retrieved from https://knlu.edu.ua/

21. Mizhnarodnyj naukovo-tekhnichnyj universytet imeni akademika Jurija Bughaja (MNTU) (2021). Retrieved from https://istu.edu.ua/

22. Kyjivsjkyj nacionaljnyj linghvistychnyj universytet (2021). Retrieved from https://knlu.edu.ua/

23. Mizhnarodnyj naukovo-tekhnichnyj universytet imeni akademika Jurija Bughaja (MNTU) (2021). Retrieved from https://istu.edu.ua/

24. Nacionaljnyj pedaghoghichnyj universytet imeni M.P.Draghomanova (2021). Retrieved from https://npu.edu.ua/ 25. Quacquarelli Symonds (2018). QS World University Rankings by Subject 2018: Linguistics. Retrieved from https://www.topuniversities.com/university-

rankings/university-subject-rankings/2018/linguistics

26. Quacquarelli Symonds (2021). QS World University Rankings by Subject 2021: Linguistics. Retrieved from https://www.topuniversities.com/university-

rankings/university-subject-rankings/2021/linguistics

27. Sanchez, M. T. (2017). The Pragmatics of Translator Training in the 21stCentury. International Journal of English Language \& Translation Studies.5(2), 81-85.

28. Simkova, I. O. (2017). Professional standards in interpreting sphere and educational requirements to future interpreters training. Vykladannja mov u vyshhykh navchaljnykh zakladakh osvity na suchasnomu etapi. Mizhpredmetni zv'jazky. Naukovi doslidzhennja. Dosvid. Poshuky, 31, 75-84.

29. Tarasenko, R. O., Amelina, S. M., \& Albert, A. A. (2019). Integrated testing system of information competence components of future translators. Proceedings of the 7th Workshop on Cloud Technologies in Education (CTE 2019), 2643, 376-391.

30. Valero-Garcés, C. (2019). Navigating between theory and practice. Design and implementation of a continuous training course for interpreters and translators of the administration. Lingua Legis, 27, 11-31.

31. Van Egdom, G. W., Segers, W., Kokaert, H., \& Cadwell, P. (2018). Ergonomics in translator and interpreter training. The Interpreter and Translator Trainer, 12(2), 252-253. https://doi.org/10.1080/1750399X.2018.1478451

32. Vidkrytyj mizhnarodnyj universytet rozvytku ljudyny «Ukrajina» (2021). Retrieved from https://uu.edu.ua/

33. Wordtips (2021). The 100 Most-Spoken Languages in the World. Retrieved from https://word.tips/100-most-spokenlanguages/

Primary Paper Section: A

Secondary Paper Section: AM 